Domínguez Vila, T., Darcy, S., \& Alén González, E. (2015). Competing for the disability tourism market - a comparative exploration of the factors of accessible tourism competitiveness in Spain and Australia. Tourism Management, 47(1), 261-272.

\title{
COMPETING FOR THE DISABILITY TOURISM MARKET - A COMPARATIVE EXPLORATION OF THE FACTORS OF ACCESSIBLE TOURISM COMPETITIVENESS IN SPAIN AND AUSTRALIA
}

\begin{abstract}
This paper seeks to address the research question of what factors make a destination competitive for the accessible tourism market. The research design is based on destination competitiveness theories. The objective is to formulate a ranking that can compare the competitiveness factors between the regions of two countries with historical and appropriate data sets for examining destination competitiveness for accessible tourism in these regions. The paper examines the background of destination competitiveness theories generally and specifically relating to the research contexts. The research design was developed to examine the underlying elements that facilitate accessible tourism experiences. The findings suggest that the competitiveness factors are different in determinance and importance depend on the country, the Spanish and Australian regions as accessible destinations have different clusters with different factors importance and determinance.
\end{abstract}

Key words: destination; competitiveness; disability; accessible tourism; Australia; Spain. 


\section{INTRODUCTION}

Research on tourism and disability has gained increasing attention over the last two decades. Particular studies have identified the constraints faced by the group (Daniels, Rodgers, \& Wiggins, 2005; Nyaupane \& Andereck, 2008; Turco, Stumbo, \& Garncarz, 1998), market dynamics (Burnett \& Bender-Baker, 2001; Domínguez, Fraiz, \& Alén, 2013; Dwyer \& Darcy, 2011; Van Horn, 2012), motivations (Figueiredo, Eusébio, \& Kastenholz, 2012; Ray \& Ryder, 2003; Shi, Cole, \& Chancellor, 2012), information needs (Buhalis \& Michopouloub, 2011; Darcy, 2010; Eichhorn, Miller, Michopoulou, \& Buhalis, 2008), crosscountry comparison (Freeman \& Selmi, 2010), disability discrimination approaches (Darcy \& Taylor, 2009; Shaw, 2007; Shaw, Veitch, \& Coles, 2005; Small \& Darcy, 2010; Veitch \& Shaw, 2011), attitudes towards people with disability (Bizjak, Knezevic, \& Cvetreznik, 2010; Daruwalla \& Darcy, 2005), attitudes of suppliers (Darcy \& Pegg, 2011; Gröschl, 2007, 2012; Kim, Stonesifer, \& Han, 2012; McKercher, Packer, Yau, \& Lam, 2003; O'Neill \& Ali Knight, 2000; Ozturk, Yayli, \& Yesiltas, 2008; Patterson, Darcy, \& Monninghoff, 2012; Tantawy, Kim, \& Pyo, 2005; Yaniv, Arie, \& Yael, 2011), whole of life approaches (Darcy \& Dickson, 2009) and needs of those with vision impairment (Poria, Reichel, \& Brandt, 2011; Richards, Pritchard, \& Morgan, 2010; Small, Darcy, \& Packer, 2012). More recently, a growing body of work has examined the processes required to incorporate disability related 
considerations within tourism policy, planning and development. Accessible tourism, as it has been named refers to the process required to ensure that transport, accommodation, destinations and attractions across the tourism system appropriately meet the needs of people with disabilities (PWD) (Buhalis \& Darcy, 2011).

It has been estimated that between 9\%-13\% of the global population (Horgan-Jones \& Ringaert, 2004; Van Horn, 2002), which today equates to approximately 650 million people (United Nations, 2006) have a disability. By 2050 this figure is set to increase to approximately 1.2 billion (United Nations \& the World Bank, 2011). Yet, there are significant relationships between ageing and disability and the relative quality life and income, where PwD face a series of constraints in their day to day life that also affect their tourism opportunities. To address the constraints, the Convention on the Rights of People with Disabilities (CRPWD) elaborates the rights of people with disabilities and sets out a procedure for nation states to implement those rights. Some 154 nations have adopted the CRPWD. The CRPWD recognises that PWD have a right to access all areas of social participation. To achieve these outcomes, the CRPWD is based on eight principles:

- Respect for inherent dignity, individual autonomy including the freedom to make one’s own choices, and independence of persons;

- Non-discrimination;

- Full and effective participation and inclusion in society;

- Respect for difference and acceptance of persons with disabilities as part of human diversity and humanity;

- Equality of opportunity;

- Accessibility;

- Equality between men and women; and 
- Respect for the evolving capacities of children with disabilities and respect for the right of children with disabilities to preserve their identities.

The eight principles are a foundation for understanding the requirements for social participation and citizenship. People should be treated as individuals, in a dignified and equitable manner no matter what their ability or gender or age. They should be treated fairly before the law so as not to be discriminated against in their endeavors for full and active participation. Diversity should not only be accepted but celebrated as part of the wonder of humanity. To achieve social participation in the broader sense people require not only an equality of opportunity but an equitable opportunity that is founded on accessibility of geographic locations across disability types and their support needs. The disability types can be classified (Domínguez , Alén \& Fraiz, 2012):

- Physical:

o Temporary restricted or ambulatory mobility: Individuals with temporary impairments that are not permanently disabling, such as persons with transitory physical disabilities that reduce their mobility, pregnant women or any other members of the population who experience temporarily reduced mobility.

o Mobility: Difficulty in maintaining and changing body postures, as well as rising, lying down, standing, sitting or relocating, which may require the use of technical support.

- Sensory

o Visual (total/partial): Disability or limited capacity to receive any image, perform synthetic or detailed visual tasks or other disabilities of vision. 
o Auditory (total/partial): Disability or limited capacity to hear any sound, to hear loud sounds or to listen to speech.

o Communication or speech (total/partial): Disability or limited capacity to communicate through speech, alternative languages, gestures that are not signed or through conventional writing and reading.

- Cognitive (intellectual or mental): Disability or limited capacity based on difficulty in recognising people or objects, orienting oneself in space and time, remembering past events or understanding and executing simple or somewhat complex orders (intellectual). Mental disability may derive from disorders caused by mental illnesses or deficiencies in intellectual capacities.

Article 30 of the CRPWD specifically recognises 'cultural life' as an important part of any person's citizenship. As the CRPWD outlines, 'cultural life' is defined as including recreation, leisure, the arts, sport and tourism. Yet, people with disabilities participate less in all forms of social participation that define an individual's identity in most countries and provides the financial resources for freedom of choice for the tourism (Barnes, Mercer, \& Shakespeare, 2010). Furthermore, a great deal of the lower levels of participation is due to discriminatory practices rather than a lack of desire to participate (Darcy \& Taylor, 2009). While many studies have identified the constraints to accessibility for PWD (Burnett \& Bender-Baker, 2001; Freeman \& Selmi, 2010), few have empirically investigated the accessibility of transport (Chang \& Chen, 2012; Darcy, 2012; Poria, Reichel, \& Brandt, 2010), accommodation (Darcy, Cameron, \& Pegg, 2010), attractions (Faria, Silva, \& Ferreira, 2012; Poria, Reichel, \& Brandt, 2009) and more broadly destinations themselves based on clear empirically testable quantitative methods. Israeli (2002) was the first to examine the relative site accessibility factors for tourists with disabilities. The study proposed a method of 
weighting for evaluating accessibility factors for tourists with disabilities at tourism sites. It did so by focusing on build environment factors including: staircases; elevators; parking; sidewalk; access ramps; paths; and restaurants. Darcy (2010) on the other hand, focused exclusively on hotel rooms where he sought to evaluate relative importance of some 55 individual criteria in hotel room accommodation choice. This study introduced the concepts of disability type (mobility, vision and hearing), access dimensions and the support needs of individuals as factors in making decisions on whether a hotel room would be accessible for an individual needs.

Yet few studies have examined destination development for disability, access or specifically target accessible tourism strategically. Ernawati and Sugiarti (2005) examined tourism attractions and facilities in a Surakarta, Indonesia and found most lacked access for people with disability and this was compounded by a lack of awareness by tourism stakeholders about PWD. Darcy, Cameron, Dwyer, and Taylor (2008) examined the accessibility of spaces and places for PWD in Australia's premier tourism precinct Sydney and Sydney Harbour. The innovative approach taken was rather than focusing on constraints to accessibility, this study identified current accessible destination experiences across commercial, government and notfor-profit providers collaborative document and promote these experiences through creating a branded understanding of accessible tourism through the Sydney for All Web portal. Kastenholz, Eusébio, Figueiredo, and Lima (2012) case study of Lousã, Portugal examined how through a stakeholder participatory approaches strategically position a small tourism destination on accessible tourism at the core to its development strategy. Central to the development of the strategy was integrating an accessible tourism vision through understanding that the outcomes would be an increased competitiveness of the destination to serve a loyal consumer group. All these three studies are commendable, none have moved beyond case study approaches that sought to empirically model or test underlying factors that 
are required to create destination competitiveness through understanding the foundations of accessible tourism within destination competitiveness frameworks.

The study context requires two countries with an appropriate history and initiatives in tourism for disability, access or accessible tourism. Further, the countries would need to have a welldeveloped tourism statistical foundation on which to examine accessible tourism. Both these considerations need to be in place in order to examine destination competitiveness. Australia and Spain offer both requisite requirements and each author has an undertaken multiple studies of accessible tourism in their respective countries.

Internationally, Australia is one of the most influential promoters of the rights of, and integration programs for, people with disabilities through the introduction of the Disability Discrimination Act in 1992 and being at the forefront of the development of the CRPWD. Australia has had a history of initiatives involving disability and access provisions in tourism, and some of the first accessible tourism initiatives (Darcy, Cameron, \& Schweinsberg, 2012). From 1998 Australia has also undertaken a National visitor survey (1998, 2003, 2009 \& 2010) that has included a limited disability module. Similarly, Spain offers a highly attractive destination for accessible tourism, principally due to its favourable climate and one of the first defender of the rights about disability with the Law of Social Integration of the disabled people in 1982, the Law of Equal Opportunities, Non-discrimination and Universal access for People with Disabilities in 2003 and the I Accessible National Planning 2004-2012. These factors mirror the important roles of people with ability impairments in the tourist sectors of both countries.

Dwyer and Darcy (2011) estimate that between 2003 and 2004, tourists with disabilities spent between AU\$8 billion to nearly AU\$12 billion and contributed AU\$3-AU\$4.5 million to Australia's tourism gross value added (GVA), or $12.27 \%-15.60 \%$ of the total tourism GVA. In Spain, the market segment includes approximately 4 million tourists, representing potential 
revenue of nearly $\$ 2.5$ billion, with a mean daily expenditure of $\$ 118$ per person over an average stay of five days, and $\$ 4,892.36$ million for an average stay of 10 days. These expenditures represent between $5.86 \%$ and $11.77 \%$ of the potential revenue earned from tourists in Spain (Domínguez et al., 2013). Nowadays, Spain ranks fourth in terms of international tourist arrivals (52.7 million) and second in international tourist receipts (\$52.5 billion) (United Nations World Tourism Organization [UNWTO], 2011). The number of international tourist arrivals in Australia has been estimated at 5.9 million, with $\$ 30.1$ million in international tourist receipts (UNWTO, 2011). Despite the importance of the tourism sector in Spain, its recent growth has been either insignificant or negative, whereas Australia has enjoyed positive growth and improved brand positioning as a tourist destination.

However, both countries have market opportunities to expand their tourism sectors with new tourist segments and quality offerings. The segment of consumers who deal with disabilities is a promising opportunity. There are 3.8 million people with disabilities in Spain (physical, sensory or cognitive), representing $8.5 \%$ of the total population. The average age of this group is 64.3 years; the number of disabled women is double that of disabled men (National Institute of Statistics [INE], 2008). Although these demographic details might appear irrelevant, they highlight the influence of Spain’s ageing population. Elderly people (i.e., those aged 65 years or older) without disabilities constitute $16.9 \%$ of the total Spanish population and Spain represents one of the world's most ageing populations. By 2020, an estimated 20\% of the population will be older than 64 years (Institute for Family Policies [IPF], 2010), and by 2050 one out of every three people will likely be at least 65 years of age (IPF, 2010). According to the World Health Organization (WHO), 35\% of people older than 65 years have some form of disability (Fuguet, 2008). Therefore, the growth of the accessible tourism market seems likely to be significant in coming years. According to WHO (2012) data, between the years of 2000 and 2050, the world population of people older than 60 years 
will double from $11 \%$ to $22 \%$. People with disabilities and elderly people are both direct beneficiaries of tourism accessibility (Burnett, 1996; Burnett \& Baker, 2001; Economic and Social Commission for Asia and Pacific, 2003; Fuguet, 2008). Together, these groups constitute more than one-fifth of the world population. Other groups that also benefit indirectly from enhanced accessibility include pregnant women, people with temporary transitory disabilities, and families with children. In other words, beneficiaries of greater accessibility could represent 31\% of total demand (Darcy \& Dickson, 2009). In Australia, 4 million people, or $18.5 \%$ of the population, have been identified as people with a disability physical, sensory or cognitive (Australian Bureau of Statistics [ABS], 2009). The rates of disability also increase with age, such that 40\% of Australians aged between 65 and 69 years and $88 \%$ of those aged 90 years and older are affected by some disability (ABS, 2009). The number of people with disabilities appears likely to increase as a result of the ageing population; the number of older people aged 65 years or older is 2.6 million, or around $13 \%$ of the Australian population, with a projected increasing trend that will reach $26 \%$ by 2051 (ABS, 2005). However, Australia has the thirteenth lowest proportion of people aged 65 years or more, projected to be $16 \%$ of the 2020 population (Organization for Economic Cooperation and Development [OECD], 2005).

This paper seeks to present an approach for competitiveness factors of tourism destinations from an accessible tourism perspective. The research proposes to present a ranking of competitiveness factors for accessible tourism destinations, where the destinations are the different tourism regions of Australia and Spain that they have in their tourism planning. The objective is to formulate an index that can compare the competitiveness factors between the regions of two countries focused on accessibility (for people with physical, sensory and cognitive disabilities) and get the different clusters destinations based on their accessibility competitiveness factors level. Accordingly, this paper summarizes some key competitiveness 
factors for accessible destinations on the basis of a comparative, competitive ranking. It also establishes different types of Spanish and Australian destinations and relevant recommendations according to their competitiveness factors.

\section{CONCEPTUAL BACKGROUND}

\subsection{Destination competitiveness theories}

The increasing interest in the competitiveness of tourist destinations has been reflected in the growing literature examining the area some studies focused on measuring competitiveness of a tourist destination (Cracolici \&Nijkamp, 2009; Croes, 2011; Cores \& Kubickova, 2013; Crouch, 2007a; D’Hauteserre, 2000; Daskalopoulou \& Petrou, 2009; De Keyser \& Vanhove, 1994; Faulkner et al., 1999; Hong, 2009; Kozak \& Rimmington, 1999; Kozak, 2001 ; Mazanec \& Ring, 2011; Mazanec, Wöber \& Zins, 2007; Pearce, 1997), attributes and factors of destination competitiveness (Crouch \& Ritchie, 1999; Crouch, 2011; Dwyer et al., 2000; Dwyer \& Kim, 2003; Enright \& Newton, 2004; Go \& Govers, 2000; Hassan, 2000; Mihalic, 2000; Navickas \& Malakauskaite, 2009; Ritchie \& Crouch, 2000), competitive strategies and indicates (Evans \& Johnson, 1995; Gooroochurn \& Sugiyarto, 2005 ). The variety of contributions has produced a multitude of considerations for understanding destination competitiveness. Croes (2011) and Mazanec, Wöber and Zins (2007) and other authors indicate that the most comprehensive definition of competitiveness has been crafted by Richie and Crouch (2003:2), who define competitiveness as "the ability to increase tourism expenditure, to increasingly attract visitors while providing them with satisfying, memorable experiences, and to do so in a profitable way, while enhancing the well-being of destination residents and preserving the natural capital of the destination for future generations”. This study draws on well-established conceptual backgrounds to analyze 
fundamental competitiveness models of tourist destinations and the approach will be now be outlined.

In particular, early authors employed a competitiveness model to recommend ways for tourist destinations to become more competitive while also improving the welfare of the local population (e.g., Crouch \& Ritchie 1994, 1995, 1999; Ritchie \& Crouch 1993, 2000). Ritchie and Crouch (2003) test and present the Conceptual Model of Destination Competitiveness, which consists of two parts: comparative; and competitive advantage. The first part focuses on resource endowments, such as human, physical, knowledge and capital resources; size of the economy; infrastructure and tourism superstructure, and cultural and historical resources. The second part deals instead with resource deployments, such as audit and inventory; maintenance; growth and development; effectiveness, and efficiency. This model acknowledges a global environment, such that the authors identify economic, technological, environmental, political, legal, sociocultural and demographic factors. They also note the influence of the microenvironment, that is, the immediate competitive environment, composed of residents, employers, mass media, financial organizations, business tourism and so forth (Ritchie \& Crouch 2003). The strengths of this model are its ambition to include all important factors that may characterize the tourism competitiveness of a destination (Mazanec, Wöber \& Zins, 2007). Although this model is widely recognized it has a number of limitations, such as the difficulty of applying it to real cases because it includes so many factors to measure, is a system of definitional rather than cause-effect relationship and it is no clear how this potential is transformed into ability. The information requirements from those indices are based on the assumption that inputs can reflect outcome expectations (Croes \& Kubickova, 2013), and the nexus between inputs and outputs are not automatic (Cores, 2011)In addition, the required data and indicators are not available in many destinations (Garau-Taberner, 2006) and use a factor analysis which always assumes reflectively 
measured latent variable (Diamantopoulos \& Winklhofer, 2001). Together this creates issues with empirically testing a model or comparing destinations.

Another important model, the Integrated Model (Dwyer \& Kim, 2003), stems from Ritchie and Crouch’s (2003) research but groups tourist policy, planning and destination development into a common management category (Crouch \& Ritchie, 2003, who classified planning and destination development as a separated factor), it then uses several main headings to indicate the determinants of destination competitiveness (Armenski et al., 2011). Competitiveness determinants include inherited resources, created resources, supporting factors and resources, destination management, situational conditions and demand conditions. In an effort to address some limitations of Ritchie and Couch’s Conceptual Model of Destination Competitiveness, Hong (2009) suggests ranking the factors and their categories by degree of importance, then measuring the factors quantitatively and analyzing the relationship between competitive and comparative advantages, as well as tourist competiveness. His conclusions suggest an importance-based factor classification, such that endowment comparative advantage appears most important (ranked at $49.18 \%$ ), followed by competitive advantage (17.27\%), tourism management (12.01\%), deployment comparative advantage (10.62\%), global environment (6.03\%), and finally the microenvironment (4.89\%) (Hong, 2009).

Among the studies of destination competitiveness, perhaps the most controversial is the Travel \& Tourism Competitiveness Index, implemented by the World Economic Forum (WEF, 2011), because countries at the top of the ranking are not necessarily strong in real tourism receipts per capita and quality life, while the current study indicated that they actually are strong in those areas (Cores \& Kubickova, 2013). It aims to measure various regulatory and business-related issues that may provide levers for improving travel and 
tourism (T\&T) competitiveness (WEF, 2011). This index has three categories, represented by three sub-indexes: T\&T regulatory framework, T\&T business environment and infrastructure, and T\&T human, cultural and natural resources. The 2011 ranking of this index placed Switzerland, Germany and France in the first three positions, followed by Austria, the United States, the United Kingdom, Spain, Canada and Singapore. However, these results do not represent true competitiveness. For example, Spain ranks as the fourth most popular tourist destination in the world but achieved only the eighth competitive position. Furthermore, Switzerland holds the first position in this index ranking but is the world's twenty-eighth most popular tourist destination (WEF, 2011; UNWTO, 2011).

Nowadays, other competitiveness measure is the tourism competitive index (TCI) (Croes, 2011), which is composed by three outputs: current performance in the global market scaled by size, dynamism of performance over time and size of the industrial base in the economic structure. This index was applied to propose a ranking of the Central American region and compare the respective performance of each country within the region. The almost ideal demand system (AIDS) model, which analyze price and income elasticities, was used for Mangion, Durbarry and Sinclair (2005) to evaluate the competitiveness of three destinations, Malta, Spain and Cyprus, offering package holidays.

\subsection{Competitiveness of Australia and Spain as tourist destinations}

Dwyer et al. (2003) use an integrated model to measure the competitiveness of Korea and Australia, attending only to the price paid by the tourist. Armenski et al. (2011) use the same integrated model for Serbia. Whereas Kozak and Rimmington (1999) study the competitiveness of Turkey from the demand perspective, Enright and Newton (2004) carry out similar research in Hong Kong from an offer perspective. De Keyser and Vanhove (1994) 
formulate a methodological proposal for the Caribbean, analyzing global environmental, offer, transport, and demand and tourism management policy resources. To apply a mixed model to Slovenia, Gomezelj (2006) and Gomezelj and Mihalic (2008) use as a reference the model proposed by De Keyser and Vanhove (1994), they then apply the integral model from Dwyer and Kim (2003). Many other studies examine the competitive positions of specific destinations, such as the United States (Ahmed \& Krohn, 1990), South Africa (Botha, Crompton \& Kim, 1999), Asia-Pacific (Enright \& Newton, 2005), Canadian ski resorts (Hudson, Ritchie \& Timur, 2004), Turkey (Kozak \& Rimmington, 1999), European cities (Mazanec, 1995), or Southeast Asia (Pearce, 1997).

A focus on Australia and Spain is convenient for the purposes of this article, namely, to reach empirical conclusions about different proposed destination competitiveness models. As will be outlined in the research design, both countries have a statistical data set that provides a foundation for comparative analysis and the history of addressing issues of disability, access and accessible tourism. In an early study of tourism in South Australia, an approach model evaluated its competitiveness within a domestic tourism context, according to eight core areas (e.g., wine tourism, Australia’s biggest river, festivals and events, heritage tourism), but its exploratory model, selective sample, and scale employed represented significant limitations (Faulkner, Oppermann \& Fredline, 1999). Dwyer et al. (2003) compare multiple tourist destinations, including Japan, Hong Kong, Malaysia, Thailand, China, Singapore, Indonesia and New Zealand, and arrive at several favourable tourism factors (Ahidé, 2005):

- Heritage resources, such as wealth, parks, landscape, flora, fauna and nature.

- Creative resources, including sport, nature and adventure activities.

- Help resources and factors, such as telecommunications, financial system and quality of services.

- Situational conditions, such as safety and destination value. 
- Destination management, including sustainable tourism relevance, reputation of the tourism organizations and satisfying customers’ needs.

- Demand conditions achieved through a generally positive image.

Unfavorable factors were also identified, including distance from the tourists’ place of origin and access to risk capital.

Spain has been the subject of other studies, such as Kozak’s (2001, 2002) comparative assessment of Mallorca (Balearic Islands) and Turkey, based on questionnaires completed by British and German tourists who chose both places as tourist destinations in 1998. The factors analyzed were accommodation services, local transport services, hygiene and cleanliness, hospitality and customer care, facilities and activities, prices, language communication, and destination airport services. The results for Mallorca highlighted the relevance of accommodation services, hygiene, prices, language communication, and facilities and activities. Other highlighted attributes included local transport prices, variety and comfort, staff attitudes, cleanliness of the destination's bars and restaurants, and the availability of facilities and services at the destination airport (Kozak, 2001).

Another notable study by Sanchez and Fajardo (2004) proposes a methodology based on the Item Response Theory. They measure the competitiveness of 45 Extremadura local governments with a two-parameter logistic model to create a destination ranking; however, there is an inherent limitation with this model as it is not a strict tourist competitiveness model. Garau-Taberner (2006, 2007) relies on two indexes to analyze competitiveness destinations - the Demand Competitiveness Index and the Tourist Industry Competitiveness Index-across five notable Mediterranean destinations: the Spanish Peninsula, the Canary Islands, the Balearic Islands, France and Italy. The Balearic Islands are a favorite destination for tourists, who cite its principal attraction factors as being the climate, landscape, 
cleanliness and hygiene, and beaches. Its worst features are accessibility for older people and children, attractions, interactions with other tourists, and the night-time atmosphere.

However, this study adopted a demand perspective, ignoring the offer and its effect on the competitiveness of a destination.

Despite the abovementioned studies of the tourism competitiveness of Spain and Australia, literature and research focused on the competitiveness of accessible destinations is nonexistent. Therefore, research into this area is warranted.

\section{RESEARCH DESIGN}

\subsection{Competitiveness model for accessible tourism}

Competitiveness cannot be measured directly and studies have used indicators for this objective, but a large number of them use inputs and outputs. Competitiveness for accessible tourism destination never has been researched and there are not output data. For this reason, it is not possible to apply indicators as WEF, TCI or AIDS, but it is possible to use Crouch and Ritchie and Kim and Dwyer model, which is based on inputs.

Crouch (2007) seeks to determine attributes that affect the competitiveness of tourist destinations, using 36 destination competitiveness attributes identified on the basis of expert judgments. Among these factors the 15 most important exhibited influences that were statistically significant and greater than the average factors, such as physiography and climate, market ties, culture and history, tourism superstructure, safety and security, cost/value, accessibility, awareness/image, location, and infrastructure. Six of these attributes constitute a core group of resources and attractors. The most important attribute, with the most significant determinant measure, is 'physiography and climate’ which shows a high, 
direct correlation with tourism attractiveness. The next most important attribute is 'culture and history', followed by 'tourism superstructure' (i.e., the quantity and quality of tourism’s constructed environment—providing tourist-specific needs such as accommodation, restaurants, transportation and recreation facilities_Crouch, 2007b). The two remaining determinant attributes, 'infrastructure’ and 'accessibility', “form part of the Supporting Factors and Resources group of attributes. This result suggests that, particularly for developing economies, one of the best forms of development that would enhance the position of the tourism industry to compete effectively would be to invest in basic infrastructural improvements” (Crouch, 2007b: 21).

Using the principal determinant attribute that experts consider to be the most critical in Crouch’s (2007) research, the present article proposes a model of the competitiveness attributes and their relevance to accessible tourist destinations. Accordingly, this research applies these competitiveness attributes to Australia and Spain, with the goal of identifying different accessible destination clusters and their characteristics. The selected attributes reflect Crouch’s $(2007,2012)$ findings about importance and determinants’ rankings. Most attributes are the same core resources and attractors, and supporting factors and resources, used by Crouch and Ritchie (2003) and in the integrated model of destination competitiveness by Kim and Dwyer (2003) (see Table 1).

\section{Insert Table 1}

Despite the presence of some other attributes — which appear less relevant, in that they are positioned among the lower half of the 36 attributes - this study of the destination, not demand, centers on resources, attractors and supporting factors. Seventeen determinant attributes are considered critical despite all competitiveness attributes requiring some 
monitoring and evaluation. The measures of the impact attributes use the attributes applied by Crouch (2007) (see Appendix 1).

The proposed model includes two focal variables: accessibility level, and number of accessible items. These focal variables and their measure were discussed with a group of experts in accessible tourism, representative of the most important disability groups (see Appendix 2), who participated as a panel. The first variable, accessibility level, was defined as the degree of access to different resources and attractions, spanning not accessible to accessible, which reflects the possibility that a person with disabilities or restricted capacities can use and enjoy something. The accessibility number variable refers to the total number of accessible destination resources and attractions. Both variables and their scales (see Appendix 3), were developed based on the criteria of experts and on the limitations of the Crouch model, which only evaluate the inputs because there are not data about accessible tourism outputs.

Different policies, regulations, and accessible strategies and plans characterize Australia and Spain’s accessible tourism regulatory framework, which likely influences the analyzed attributes, such as tourism superstructure, infrastructure, and entertainment, all of which are linked to architecture, urban planning, transport, and communication factors. These are in turn influenced by regional and national government policies. This influence constitutes a challenging problem, that is, in different local governments in the same country have unique disability and accessibility policies.

\subsection{Methodology}


To analyze the number and level of the attributes for accessible destination competitiveness, this study used quantitative data. It sought to identify the competitive attributes of Australian and Spanish accessible tourism destinations, according to a comparative and competitive ranking, as well as establish different types of Spanish and Australian destinations and their behavior on the basis of the analyzed competitiveness factors. In addition, this research used secondary data, such that one analyzed case equals one destination $(N=n)$. The key variable is geographic and tourist divisions (Appendix 4) of Spanish and Australian governments used the tourism plan of both countries:

- Spain: 17 regions with 52 provinces.

Sample size: 52 cases.

- $\quad$ Australia: 8 states with 61 regions.

Sample size: 61 cases.

The data were collected between February and June 2013 and the main competitiveness attributes for accessible tourism. The collection of the secondary data relied on two resources: (i) official tourism websites of different destinations and (ii) information about disability, accessible tourism and guidebooks for accessible destinations (Appendix 3). The data come from many different and varied sources but is possible the comparison because they have the same characteristic, they are the web official sources of all tourist destinations. This methodology was deemed appropriate because the research aim is to analyze competitiveness destination resources with the same method and as the data is focused on measure the accessibility of tourism destinations, there are few paper references. Shi (2006), one of the few existing, studies the accessibility of Queensland visitor information centers’ websites, because World Wide Web has been seen as the most effective advertising and marketing tool (Kasavana, Knuston \& Polonowski, 1997) and many users of the web have various types of disability. . In addition “destination competitiveness is more concerned with a destination’s 
capacity to achieve a set of goals, some of which may relate to measures of demand, but which often extend much further to address broader economic, social, and environmental outcomes, $[\ldots]$ an undue emphasis on demand alone would be narrow and potentially misleading” (Crouch, 2012: 31).

\section{ANALYSIS AND DISCUSSION}

The main analysis variable, accessibility, comprises two dimensions: (i) number of accessibility products and services offered by Australian and Spanish tourist destinations and (ii) their levels of accessibility. For the data analysis, these dimensions were combined into a single, unique variable. In turn, the data analysis pursued two main insights. First, with a competitiveness model analysis for accessible tourist destinations, this research seeks to determine the principal competitiveness factors and attributes for accessible destinations. Second, the development of a cluster analysis of the different tourist destinations within Australia and Spain uses these established factors and attributes. A comparative analysis of both countries and their accessible tourist destinations provides further insights.

\subsection{Competitiveness accessible destination}

Applying Crouch’s competitiveness model to Australian and Spanish destinations reveals that the five factors proposed by Crouch can be reduced to four. Destination management and destination policy, planning and development can be grouped into a destination planning and management factor, according to their similar characteristics (see Table 1). A principal component analysis is applied with the limitation to use reflectively measured latent variable (Diamantopoulos \& Winklhofer, 2001). 
For both the Australian and Spanish cases, these factors and attributes affirmed the high reliability of the model. The Cronbach's alpha was better for the Australian than the Spanish data but representative for both (Table 2). In Australia, the statistical adjustment was similar for all factors, that is, all of them have a high representation for the model used, with the exception of the slightly lower value for qualifying and amplifying determinants. Spain showed the same pattern but with lower values, and qualifying and amplifying determinants were not representative. Every factor fulfilled the Kaiser-Meyer-Olkin and Bartlett’s sphercity test requirements.

\section{Insert Table 2}

However, the most important destination competitiveness attributes, in terms of accessibility, differed for Australia and Spain. In descending order of importance for Australia, the five attributes with the greatest relevance were quality of services/experience, positioning and branding, infrastructure, physiography and climate, accessibility, and culture and history. The main Australian attributes focused on two factors: (i) destination planning and management, and (ii) supporting factors and resources. Australia has to improve its efforts about accessibility through infrastructure development and politics. This behavior is motivated by Australia's relatively young tourism tradition and the difficulty associated with improving its positioning as a global destination.

Spain, as an international tourism reference, offered better destination planning and management; its supporting factors and resources were highly developed. Regarding its competitiveness for accessible destinations, the five most relevant attributes were physiography and climate, tourism superstructure, location, awareness/image, and positioning and branding. These aspects were not only the main characteristics of tourism activity in 
Spain but also the strategic focus of its competitive advantage. Spain’s accessible tourism offer used the same strategic resources to attract tourists.

In neither Australia nor Spain was the offer based on safety and security-one of the most important attributes for tourists with disabilities. No common or standardized norm exists for offering high quality, honest tourist information. This gap is a substantial problem for disabled people, who must conduct thorough research into destinations and related tourist services and products, before travelling. This relevant element exerts a powerful influence on their purchase decisions.

Having established the importance of the factors and attributes, it becomes necessary to determine the extent to which they are determinant elements (Table 3) and a t-test analysis is used. All attributes showed statistical significance in both cases, but the Australian and Spanish offers differed. The Australian offer depended on the cost and value of the tourism products, lack of tourism superstructure, and physiography and climate. The distance, trip costs and size of the country consistently remain difficult problems to manage, because they are inherent structural issues that are impossible to change. The most determinant competitiveness attributes for Spain were its infrastructure, tourism superstructure, and safety and security.

\section{Insert Table 3}

In terms of attribute importance the behavior of both countries, as manifested in their offers, differed between the determinants and importance measures (Table 4). The factors with most weight for Australia were core resources and attractions (as was the case for Spain), followed by destination planning and management, supporting factors and resources, and qualifying and amplifying determinants. But in Spain, resources and attractors were followed by supporting factors and resources, qualifying and amplifying determinants, and then 
destination planning and management. Australia focused on planning and management of its resources and attractors whereas Spain focused more on its resources and supports.

In an analysis based on the importance of the attributes, the key points for Australia were quality, branding and positioning, and infrastructures. These elements had more relevance for designing accessible tourist products and services. For Spain, the most important factors were the same for accessible tourism and other tourism offers: physiography and climate, tourism superstructure and location.

\section{Insert Table 4}

The comparison between the determinacy and importance of factors and attributes also highlighted many differences between Australian and Spanish accessible destinations. Table 5 summarizes the results related to the first research objective, namely, to determine the importance, influence, and order of the competitiveness factors and attributes of Australian and Spanish accessible destinations. A rank order of the main factors and attributes, in terms of the estimated importance weights and respective level of determinance, thus can be established (Crouch, 2013).

\section{Insert Table 5}

Both countries exhibited notable differences between determinacy and importance rankings. For Australia, the most important attributes focused on the quality and destination brand, whereas those for the accessible offer were cost and the tourist structure, due to the location, geography and size of Australia. These were also the most important attributes for Spain, which has a long tourist tradition; however, the determinant attributes of the accessible tourism offer instead were infrastructure, tourist infrastructure, and safety and security. 


\subsection{Clusters of accessible destinations according to competitiveness attributes}

Establishing the main competitiveness factors for Australian and Spanish accessible destinations, and their statistical significance, was the second goal of this research. Thus, this study applied cluster analysis to Australian and Spanish accessible tourist destinations using Crouch’s competitiveness attributes.

The first step involved exploring the relationship between the attributes and the 61 Australian and 52 Spanish tourist destinations, according to a hierarchical cluster analysis. With dendograms and their hierarchical relationship, it was possible to develop a second cluster analysis with k-means clustering, which helped establish the number of clusters for both cases. The k-means cannot help to determinate the exact number of clusters, and the CalinskiHarbasz index $(\mathrm{CH})$ is used. This index is based on the calculation of variance between cluster centers divided by sum of within cluster variance (Dolnicar \& Leisch, 2010). The dendogram and the k-means calculated for Australia determined between 4 and 6 clusters, and the $\mathrm{CH}$ highest was for 5 clusters (775.59 for 5 clusters, 691.37 for 6 clusters and 660.99 for 4 clusters). In the case of Spain, the dendogram and the k-means established between 5 and 7 clusters, and the $\mathrm{CH}$ highest was for 6 clusters (377.03 for 6 clusters, 368.48 for 5 clusters and 347.53 for 4 clusters). As Table 6 shows, the cluster analysis indicated a statistical significance of .000 for Australia and Spain, with five and six clusters, respectively.

\section{Insert Table 6}

The behaviors of the Australian clusters differed widely. Cluster 2 (Sydney), and Cluster 3 (Melbourne) were the most accessible destinations, in terms of the previously established competitiveness attributes. The difference between these cities pertained to the quantity and quality of accessible information about tourist products and services, as well as their respective geography and urban planning. Melbourne provided more, and a higher level, of 
accessible offers. Both cities identified new market opportunities, and focused on disabled and elderly people, which granted them greater competitive advantages.

Cluster 1 includes seven tourist destinations (see Table 7), all of which included attractive offers for different types of tourists despite only just beginning to work on accessible offers through public and political programs and private initiatives. Therefore, these destinations offer high potential insofar as they could develop a range of tourist attraction products and services. On the other hand, Cluster 4 lacks a strong offer in terms of accessible tourist resources, with limited general and specific tourist infrastructures and no political or planning designs for accessibility. Cluster 5, the biggest group with 31 destinations, also contains the fewest competitiveness accessible destinations, due to various structural, geographic, political, urban planning and tourist management problems. This trend appears likely to persist.

\section{Insert Table 7}

Spain has one more clusters than Australia; as noted, it is a tourist destination with greater relevance and tradition and a very well-developed tourism industry. The main cities are also the most accessible destinations (i.e., Madrid and Barcelona), as was the case in Australia. However, Madrid and Barcelona enjoy better branding, positioning and images than either Melbourne or Sydney. Therefore, Clusters 2 and 4 are tourist destinations with a high degree of importance and good positioning, because of their relevant tourist attractions. While destinations in Cluster 4 focus more on accessible tourist offers, Cluster 2 destinations are in the process of designing accessible programs.

Cluster 3, which is the largest and most heterogeneous group and are potential accessible destinations because all of them are have important tourist attractions but only have some accessible actions or are designing an accessible tourist plan Cluster 1 indicates high potential, with its many tourist attractions, but it is only beginning to develop its first 
accessibility projects. Finally, Cluster 5 produces the worst results; it includes destinations with low tourist attraction and accessibility.

The results across both countries emphasize the importance of a destination's image and reputation in the tourism market. A destination's attractive qualities should be highlighted in high-quality information about the accessible level and number of products and services that are offered. Providing such information has a direct influence on purchase decisions, cost and security competitiveness.

\section{CONCLUSIONS AND LIMITATIONS}

The findings outlined in this research suggest several conclusions. In particular, the Crouch competitiveness model is applicable to accessible tourist destinations, although the revised model consists of four instead of five factors, because destination management is similar enough to destination policy, planning and development that they can be combined in a single factor, called “destination planning and management”. This factor is critical to the development of accessible tourism provisions as it sets the underlying infrastructure for transport, accommodation and attractions.

The attributes of the model reveal a differentiated pattern, according to whether the focus is determinacy or importance. In terms of determinacy, the key attributes in the competitiveness analysis for accessible tourist destinations are tourism superstructure, cost and value, and safety/security. These features have a common key element, namely, the importance and relevance of the tourist products offered through secure, truthful, high quality and accessible information. Information about accessible tourist products is not homogeneous or standardized, which reflects the various types of disability that each consumer might face. Therefore the cost and value of relevant products and services are higher, because they must guarantee an accessible product for all tourists, a priori. Despite these patterns, the 
importance rankings of the attributes put the key elements in less prominent positions. Intrinsic tourist attractions, such as the climate, locale and tourist structure, are most important for Spain, whereas the quality of services, brand and infrastructure are of great importance for Australia.

This above behavior is highlighted in the analyses of the different tourist destinations. Both countries, with their varying number of clusters, present similar patterns. Tourist destinations, such as big cities and capitals, provide high levels of accessibility in their tourist offer (e.g., Sydney, Melbourne, Barcelona and Madrid). Other destinations with important tourist attractions suggest three main stages: (i) destinations working on accessibility with specific offers, (ii) those that have identified the market opportunity and are including accessibility as a differentiator in their policies, and (iii) destinations that are not working on accessibility and therefore will not take advantage of this segment or, indirectly, of elderly and family tourism. The last stage indicates the likelihood of tourist destinations with low tourist attraction and low or invalid levels of accessibility.

In terms of the competitiveness of both countries and their respective tourist destinations, Spain enjoys a better position because it has a long tourism tradition, defined by its favorable location, climate, politics and specific accessibility laws. Australia, despite significant progress due to the 2000 Olympic Games in Sydney, has legislative shortcomings and lacks a clear political strategy toward accessible tourism.

However, the results of this study also exhibit some limitations. The investigation reflects a survey of tourist destination offers, without accounting for customer opinions. In so doing, it identifies the information about accessibility products and services available to a potential or real tourist with disabilities. Increasing mobility trends in tourism means that offers must focus on global, not just local, markets. Yet with these data, it was impossible to analyze each 
offer in situ. Despite this limitation of the analysis, the results offer strong relevance and interest, in that the evaluated information is the same information users can access, and all destinations can be analyzed using the same items (Appendix 1). Thus, it becomes possible to measure the competitiveness of accessible tourist destinations.

Another limitation is that only the Crouch attributes with substantial relevance appeared in the analysis. Others created difficulties with regard to accessibility measures, and "it is quite likely that some of the attributes of destination competitiveness will be much more important than others in terms of their impact” (Crouch, 2011: 40). These limitations suggest opportunities for further research. It would be interesting to study destinations with high accessibility—using offer and demand perspectives_-and then test for coherence across these perspectives. Studying some factors and attributes individually could also prove relevant as a means to obtain more detailed information.

In turn, these considerations could help improve the performance of the tourism industry, by facilitating its adaptation to future tourist trends marked by a greying population and the increased heterogeneity of consumers with differentiated abilities. And as a consequence, it could benefit the global society as a whole by encouraging the creation of tourist destinations for all.

\section{BIBLIOGRAPHY}

- Aitchison, C. (2003). “From leisure and disability leisure: developing data, definitions and discourses”. Disability and Society, Vol. 18 (7): 955-969.

- Ahidé, D. (2005). “Turismo y Competitividad en Venezuela: Una Aproximación a la Situación Actual Venezolana”. Visión Gerencial, Vol. 4 (2):.133-150. 
- Ahmed, Z.U. and Krohn, F.B. (1990). "Reversing the United States Declining Competitiveness in the Marketing of International Tourism: A Perspective on Future Policy”. Journal of Travel Research, Vol. 29 (2): 23-29.

- Australian Bureau of Statistics -ABS- (2009). Disability, ageing and carers, Australia: summary of findings. Available from: http://www.ausstats.abs.gov.au/ausstats /subscriber.nsf/0/9C2B94626F0FAC62CA2577FA0011C431/\$File/44300_2009.pdf

- Australian Bureau of Statistics. (2005). Health of Older People in Australia: A Snapshot, 2004-05. Available from: http://www.abs.gov.au/ausstats/abs@.nsf/mf /4833.0.55.001/

- Armenski, T., Marković, V., Davidović, N. and Jovanović, T. (2011).”Integrated Model of Destination Competitiveness”. Geographica Pannonica, Vol. 15 (2): 58-69.

- Bizjak, B.; Kneževic', M. and Cvetrežnik, S. (2011). “Attitude change towards guests with disabilities: reflections from tourism students”. Annals of Tourism Research, Vol. 38(3): 842-857.

- Botha, C., Crompton, J.L. and Kim, S. (1999).” Developing a Revised Competitive Position for Sun/Lost City, South Africa”. Journal of Travel Research, Vol. 37 (4): 341-352.

- Buhalis, D. and Darcy, S.(2011). Accessible Tourism: Concepts and Issues. Channel View Publications, UK.

- Buhalis, D., and Michopouloub, E. (2011).’Information-enabled tourism destination marketing: Addressing the accessibility market”. Current Issues in Tourism, 14(2): 145168.

- Buhalis D., Eichhorn, V., Michopoulou E. and Miller G. (2005). Accessibility Market and Stakeholder Analysis 2005. OSSATE/ University of Surrey, Surrey. 
- Burnett, J.J. and Baker, H. (2001). “Assessing the Travel-Related Behaviours of the MobilityDisabled Consumer”. Journal of Tavel Research, Vol. 40 (1): 4-11.

- Chaiboonsri, C., and Chaitip, P. (2008). “A structural equation model: Thailand's international tourism demand for tourist destinations”. Annals of the University of Petrosani. Economics, Vol. 8 (2): 107-134.

- Chang, Y.-C., and Chen, C.-F.(2012). "Meeting the needs of disabled air passengers: Factors that facilitate help from airlines and airports”. Tourism Management, 33(3): 529-536.

- Cores, R. (2011). “Measuring and explaining competitiveness in the context of small island destinations”. Journal of Travel Research, Vol. 50 (4): 431-442.

- Croes, R. \& Kubickova, M. (2013). “From potential to ability to compete: towards a performance-based tourism competitiveness index”. Journla of Destination Marketing \& Management, Vol. 2 :146-154.

- Cracolici, M., F. and Nijkamp, P. (2009). “'The Attractiveness and Competitiveness of TouristDestination: A study of Southern Italian Regions'”. Tourism Management, Vol. 30 (3): $336-344$.

- Crouch, G.I. (2011). “ Destination competitiveness: an analysis of determinant attributes”. Journal of Travel Research, Vol. 50 (1): 27-45.

- Crouch, G.I. (2007a). “Measuring tourism competitiveness: research, theory and the WEF Index”. ANZMAC 2007 - Reputation, Responsibility, Relevance. 3-5 December, pp. 73-79.

- Crouch, G.I. (2007b). Modelling destination competitiveness. A survey and analysis of the impact of competitiveness attributes. CRC for Sustainable Tourism Pty Ltd, Australia.

- Crouch, G.I. and Ritchie, J.R.B. (1999). “Tourism, competitiveness and societal prosperity”. Journal of Business Research, Vol. 44 (3): 137-152. 
- Crouch, G.I. and Ritchie, J.B.R. (1995). "Destination Competitiveness and the Role of the Tourism Enterprise”. Proceedings of the Fourth Annual World Business Congress, July 1316, Turkey: 43-48.

- Crouch, G.I. and Ritchie, J.B.R. (1994). “Destination Competitiveness: Exploring Foundations for a Long-Term Research Program”. Proceedings of the Administrative Sciences Association of Canada 1994 Annual Conference, June 25-28, Nova Scotia: 79-88.

- Daniels, M.J., Drogin, E.B. and Wiggins, B.P. (2005). ““Travel Tales”: An interpretative analysis of constraints and negotiations to pleasure travel as experienced by persons with physical disabilities”. Tourism Management, Vol. 26 (6): 919-930.

- Darcy, S. (2012). “(Dis)embodied air travel experiences: Disability, discrimination and the affect of a discontinuous air travel chain”. Journal of Hospitality and Tourism Management, 19(e8 August): 1-11.

- Darcy, S. (2010). “Inherent complexity: Disability, accessible tourism and accommodation information preferences”. Tourism Management, Vol. 31 (6): 816-826.

- Darcy, S. (2002). “Marginalised participation: Physical disability, high support needs and tourism”. Journal of Hospitality and Tourism Management, Vol. 9 (1): 61-72.

- Darcy, S. and Buhalis, D. (2011). “Conceptualising Disability: Medical, Social, WHO ICF, Dimensions and Levels of Support Needs”. In Accessible Tourism: Concept and Issues, Ed. by Buhalis, D. and Darcy, S. Channel View Publications, UK: 21-42.

- Darcy, S., Cameron, B., Dwyer, L. Taylor, T., Wong, E. and Thomson, A. (2008). Visitor accessibility in urban centres. CRC for Sustainable Tourism Pty Ltd, Australia.

- Darcy, S., Cameron, B., \& Pegg, S. (2010). “Accessible tourism and sustainability: A discussion and case study”. Journal of Sustainable Tourism, 18(4): 515 - 537. 
- Darcy, S., Cameron, B., \& Schweinsberg, S. ()2012. Accessible tourism in Australia. In Best practice in accessible tourism: Inclusion, disability, ageing population and tourism, edited by D. Buhalis, S. Darcy \& I. Ambrose. Bristol, UK: Channel View Publications: 79-113.

- Darcy, S. and Dickson, T. (2009). “A whole-of-life approach to tourism: The case for accessible tourism experiences”. Journal of Hospitality and Tourism Management, Vol. 16 (1): 32-44.

- Darcy, S., and Pegg, S. (2011). “Towards strategic intent: Perceptions of disability service provision amongst hotel accommodation managers”. International Journal of Hospitality Management, 30(2): 468-476.

- Darcy, S., and Taylor, T. (2009). "Disability citizenship: An Australian human rights analysis of the cultural industries”. Leisure Studies, 28(4): 419-441.

- Daruwalla, P., and Darcy, S. (2005). "Personal and societal attitudes to disability”. Annals of Tourism Research, 32(3): 549-570.

- Daskalopoulou I. and Petrou A.(2009). “Urban Tourism Competitiveness: Networks and the Regional Asset Base”. Urban Studies, Vol. 46 (4): 779-80.

- De Keyser, R. and Vanhove, N. (1994). “The competitive situation of tourism in the Caribbean area— Methodological approach”. Revue de Tourisme, Vol. 49 (3): 19-22.

- D’Hauteserre, A.-M. (2000). “Lessons in managed destination competitiveness: the case of Foxwoods casino resort”. Tourism Management, Vol. 21 (1): 23-32.

- Diamantopoulos, A. and Winklhofer, M. (2001). “Index construction with formative indicators: an alternative to scale development”. Journal of Marketing Research, Vol. 38 (2) : 269- 276. 
- Dolnicar, S. and Leisch, F. (2010). “Evaluation of strucutre and reproducibility of cluster solutions using the bootstrap”. Marketing Letters, Vol.21: 83-101.

- Domínguez, T., Fraiz, J.A. and Alen, E. (2013). “Economic profitability of accessible tourism for the tourism sector in Spain”. Tourism Economics, Vol. 19 (6): 1385-1399.

- Domínguez, T., Alén, E., and Fraiz, J.A. (2013). “International accessibility: a proposal for a system of symbols for people with disabilities”. International Journal of Disability and Human Development, Vol. 12 (3): 235-243.

- Dwyer, L., and Darcy, S. (2011). Economic contribution of tourists with disabilities: An Australian approach and methodology. In Accessible tourism: Concepts and issues edited by D. Buhalis \& S. Darcy. Bristol, UK: Channel View Publications: 213-239.

- Dwyer, L., Forsyth, P. and Rao, P. (2000). “Sectoral analysis of price competitiveness of tourism: An international comparison”. Tourism Analysis, Vol. 5 (1): 1-12.

- Dwyer, L. and Kim, C. (2003). “Destination competitiveness: Determinants and indicators”. Current Issues in Tourism, Vol. 6 (5): 369-414.

- Eichhorn, V., Miller, G.; Michopoulou, E. and Buhalis, D. (2008). “Enabling access to tourism through information schemes”. Annals of Tourism Research, Vol. 35 (1): 189-210.

- Enright, M.J. and Newton, J. (2005). “Determinants of Tourism Destination Competitiveness in Asia Pacific: Comprehensiveness and Universality”. Journal of Travel Research, Vol. 43 (4): 339-350.

- Ernawati, D. B., and Sugiarti, R. (2005). “Developing an accessible tourist destination model for people with disability in indonesia”. Tourism Recreation Research, 30(3): 103-106.

- Enright, M. J. and Newton, J. (2004). “Tourism destination competitiveness: a quantitative approach”. Tourism Management, Vol. 25 (6): 777-788. 
- Evans, M. R. and Johnson, R. B. (1995). “Identifying competitive strategies for successful tourism destination development”. Journal of Hospitality and Leisure Marketing, Vol. 31 (1): 37-45.

- Faria, M. D. d., Silva, J. F. and Ferreira, J. B. (2012). “The visually impaired and consumption in restaurants”. International Journal of Contemporary Hospitality Management, 24(5): 721-734.

- Faulkner, B., Oppermann, M. and Fredline, E. (1999). “Destination competitiveness: An exploratory examination of South Australia's core attractions”. Journal of Vacation Marketing, Vol. 5 (2): 125-139.

- Figueiredo, E., Eusébio, C. and Kastenholz, E. (2012). How diverse are tourists with disabilities? A pilot study on accessible leisure tourism experiences in portugal. International Journal of Tourism Research, DOI: 10.1002/jtr.1913

- Freeman, I. and Selmi, N. (2010). "French versus Canadian Tourism: Response to the Disabled”. Journal of Travel Research, Vol. 49 (4): 471-485.

- Fuguet, T. (2008). “Europa demanda más accesibilidad”. Editur, N. 07, Jul: 10-15.

- Garau-Taberner, J. (2007). “Measuring Destination Competitiveness: An Exploratory Study of the Canaries, Mainland Spain, France, the Balearics and Italy”. Tourism Today, Fall 2007: 61-77.

- Garau-Taberner, J.(2006). “Propuesta de dos índices para la mediación de la competitividad de los destinos de sol y playa del Mediterráneo: avance de resultados desde el punto de vista de la demanda”. XV Simposio Internacional de turismo y ocio, 3 May, ESADE-Fira Barcelona, Spain.

- Gilson, S.F. and Depoy, E. (2000). "Multiculturalism and Disability: A Critical Perspective”. Disability and Society, Vol. 15 (2): 207-218. 
- Go, F.M. and Govers, R. (2000). "Integrated quality management for tourist destinations: a European perspective on achieving competitiveness”. Tourism Management, Vol. 21 (1): 79-88.

- Gomezelj, D. (2006). “Competitiveness of Slovenia as a tourist destination”. Managing Global Transitions, Vol. 4, (2): 167-189.

- Gomezelj, D.O. and Mihalič, T. (2008). “Destination competitiveness-Applying different models, the case of Slovenia”. Tourism Management, Vol. 29 (2): 294-307.

- Gooroochurn, N., and Sugiyarto, G. 2005. Competitiveness indicators in the travel and tourism industry. Tourism Economics, Vol. 11 (1), pp. 25-43.

- Gröschl, S. 2012. Presumed incapable: Exploring the validity of negative judgments about persons with disabilities and their employability in hotel operations. Cornell Hospitality Quarterly.

- Gröschl, S. (2007). “An exploration of hr policies and practices affecting the integration of persons with disabilities in the hotel industry in major canadian tourism destinations”. International Journal of Hospitality Management, 26(3): 666-686.

- Hassan, S.S. (2000). “Determinants of market competitiveness in an environmentally sustainable tourism industry”. Journal of Travel Research, Vol. 38 (3): 239-245.

- Hong, W. (2009). “Global competitiveness measurement for the tourism sector”. Current Issues in Tourism, Vol. 12(2): 105-132.

- Horgan-Jones, M. \& Ringaert, L. (2004). “Accessible Tourism in Manitoba”. 04.03.2007, Available from: http://www.ttra.com/pub/uploads/AccessibleTourismInManitoba.htm 
- Hudson, S., Ritchie, J.R.B. and Timur, S. (2004). “Measuring Destination Competitiveness: An Empirical Study of Canadian Ski Resorts”. Tourism Hospitality Planning and Development, Vol. 1 (1): 79-94.

- Institute for Familiary Politic -IPF-, (2010). Evolución de la familia europea, 2010.

- Israeli, A. (2002). “A Preliminary Investigation of the Importance of Site Accessibility Factors for Disabled Tourists”. Journal of Travel Research, Vol. 41 (1): 101-104.

- Kasavana, L.K., Knuston, B.J. and Polonowski, S.J. (1997). “Nellurking: the future of hospitality Internet marketing”. Journal of Hospitality and Leisure Marketing, Vol. 5 (1): $31-44$.

- Kastenholz, E., Eusébio, C., Figueiredo, E., \& Lima, J. (2012). “Accessibility as competitive advantage of a tourism destination: The case of lousã”. Field guide to case study research in tourism, hospitality and leisure, Vol. 6: 369-385.

- Kim, W. G., Stonesifer, H. W., and Han, J. S. (2012). “Accommodating the needs of disabled hotel guests: Implications for guests and management”. International Journal of Hospitality Management, 31(4): 1311-1317.

- Kozak, M. (2002). “Comparative analysis of tourist motivations by nationality and destinations”. Tourism Management, Vol. 23 (3): 221-232.

- Kozak, M. (2001). “Repeaters’ behaviour at two distinct destinations”. Annals of Tourism Research, Vol. 28 (3): 784-807.

- Kozak, M. and Rimmington, M. (1999). "Measuring tourist destination competitiveness: conceptual considerations and empirical findings”. International Journal of Hospitality Management, Vol. 18 (3): 273-283. 
- Mangion, M.L., Durbarry, R. and Sinclair, M.T. (2005). “ Tourism Competitiveness: price and quality”. Tourism Economics, Vol. 11 (1): 45-68.

- Mazanec, J.A. and Ring, A. (2011). “Tourism destination competitiveness: second thoughts on the World Economic Forum reports”. Tourism Economics, Vol. 17 (4): 725-751.

- Mazanec, J.A., Wöber, K. \& Zins, A.H. (2007). “Tourism destination competitiveness: from definition to explanation?”. Journal of Travel Research, Vol. 46: 86-95.

- Mazanec, J.A. (1995). “Competition among European Tourist Cities: A Comparative Analysis with Multidimensional Scaling and Self-Organizing Maps”. Tourism Economics, Vol. 1 (3): 283-302.

- McKercher, B., Packer, T. L., Yau, M.K. and Lam, P. (2003). “Travel agents as facilitators or inhibitors of travel: perceptions of people with disabilities”. Tourism Management, Vol. 24. (4): $465-474$.

- Mihalic, T. (2000). "Environmental management of a tourist destination: A factor of tourism competitiveness”. Tourism Management, Vol. 21 (1): 65-78.

- Miles, M. (2000). “Disability on a Different Model: glimpses of an Asian heritage”. Disability \& Society, Vol. 15 (4): 603-618.

- National Institute of Statistics -INE-. (2008). Encuesta sobre Discapacidad, Deficiencia y Estado de la Salud -EDDES-, 2008.

- Navickas, V. and Malakauskaite, A. (2009). “The Possibilities for the Identification and Evaluation of Tourism Sector Competitiveness Factors”. Engineering Economics, Vol. 1 (61): 37-44.

- Nyaupane, G. P., and Andereck, K. L. (2008). “Understanding travel constraints: Application and extension of a leisure constraints model”. Journal of Travel Research, 46(4): 433-439. 
- O'Neill, M., and Ali Knight, J. (2000). “Disability tourism dollars in western Australia hotels”. FIU Hospitality Review, 18(2): 72-88.

- Organisation for Economic Co-Operation and Development -OECD-. (2005). “Ageing Populations: High Time for Action”. Meeting of G8 Employment and Labour Ministers, London, 10-11 March 2005.

- Ozturk, Y., Yayli, A. and Yesiltas, M. (2008). "Is the Turkish tourism industry ready for a disabled customer's market? The views of hotel and travel agency managers”. Tourism Management, Vol. 29 (2): 382-389.

- Patterson, I., Darcy, S., and Monninghoff, M.(2012). “Attitudes and experiences of tourism operators in northern Australia toward people with disabilities”. World Leisure Journal, 54(3): 215-229.

- Pearce, F.G. (1997). “Competitive destination analysis in Southeast Asia”. Journal of Travel Research, Vol. 35 (4): 16-24.

- Poria, Y., Reichel, A. and Brandt, Y. (2011). “Blind people’s tourism experiences: An exploratory study”. In Accessible tourism: Concepts and issues, edited by D. Buhalis \& S. Darcy. Bristol, UK: Channel View Publications: 149-159.

- Poria, Y., Reichel, A. and Brandt, Y. (2010). “The flight experiences of people with disabilities: An exploratory study”. Journal of Travel Research, 49(2): 216-227.

- Poria, Y., Reichel, A. and Brandt, Y. (2009). "People with disabilities visit art museums: An exploratory study of obstacles and difficulties”. Journal of Heritage Tourism, 4(2): 117 129

- Rangaswamy, N., Chaiboonsri, C. and Chaitip, P. (2008). “A structural equation model: India's international tourism demand for tourist destinations”. Annals of the University of Petrosani. Economics, Vol. 8 (2): 107-134. 
- Ray, N. and Ryder, M. (2003).”“Ebilities” Tourism. An Exploratory Discussion of the Travel Needs and Motivations of the Mobility Disabled”. Tourism Management, Vol. 24 (1): 5772.

- Richards, V. Pritchard, A. and Morgan, N. (2010). “(Re)Envisioning Tourism and Visual Impairment”. Annals of Tourism Research, Vol. 37 (4): 1097-1116.

- Ritchie, J.R.B. and Crouch, G.I.( 2003). The Competitive Destination: A Sustainable Tourism Perspective, CABI Publishing, Wallingford, UK.

- Ritchie, J.R.B. and Crouch, G.I. (2000). “The Competitive Destination. A Sustainable perspective”. Tourism Management, Vol. 21 (1): 1-7.

- Ritchie, J.R.B. and Crouch, G.I. (1993). “Competitiveness in international tourism: a framework for understanding and analysis”. Proceedings of the $43^{\text {rd }}$ Congress of International Association of Scientific Experts in Tourism, 17-23 October, Argentina: 2371.

- Sánchez, M. and Fajardo, M.A. (2004). “La competitividad de los destinos turísticos: un análisis cuantitativo mediante modelos logísticos. Aplicación a los municipios extremeños”. I Jornadas de Economía del Turismo. 28 - 29 May, Palma de Mallorca, Spain: 1-21.

- Shaw, G. (2007). "Disability legislation and empowerment of tourists with disability in the united kingdom”. In Tourism, power and space edited by A. Church \& T. Colespp. London: Routledge: 83-100.

- Shaw, G., Veitch, C. and Coles, T. (2005). “Access, Disability, and Tourism: Changing Responses in the United Kingdom”. Tourism Review International, Vol. 8: 167-176.

- Shi, Y. (2006). “The accessibility of Queensland visitor information centres’websites”. Tourism Management, Vol. 27: 829-841. 
- Shi, L., Cole, S. and Chancellor, H. C. (2012). "Understanding leisure travel motivations of travelers with acquired mobility impairments”. Tourism Management, 33(1): 228-231.

- Small, J., and Darcy, S.( 2010). “Tourism, disability and mobility”. In Tourism and inequality: Problems and prospects, edited by S. Cole \& N. Morganpp. Wallingford: CABI: $1-20$.

- Small, J., Darcy, S., and Packer, T. (2012). “The embodied tourist experiences of people with vision impairment: Management implications beyond the visual gaze”. Tourism Management, 33(4): 941-950.

- Tantawy, A., Kim, W. G. and Pyo, S. (2005). “Evaluation of hotels to accommodate disabled visitors”. Journal of Quality Assurance in Hospitality \& Tourism, 5(1): 91 - 101.

- Turco, D. M., Stumbo, N. and Garncarz, J. (1998). “Tourism constraints - people with disabilities”. Parks and Recreation Journal, 33(9): 78-84.

- United Union.( 2006). “Some Facts about Persons with Disabilities”. International Convention on the Rights of Persons with Disabilities. United Union, New York, 14-25 August 2006.

- Van Horn, L. (2012). The united states: Travellers with disabilities. In: Best practice in accessible tourism: Inclusion, disability, ageing population and tourism_, edited by D. Buhalis, S. Darcy \& I. Ambrose. Bristol, UK: Channel View Publications: 65-78.

- Van Horn, L. (2002). Travellers with Disabilities: Market Size and Trends. Available from: http://ncpedp.org/access/isu-travel.htm

- Veitch, C. and Shaw, G. (2011). “Disability legislation and empowerment of tourists with disability: The UK case”. In Accessible tourism: Concepts and issues edited by D. Buhalis \& S. Darcy. Bristol, UK: Channel View Publications: 62-72. 
- World Economic Forum -WEF-. (2011). The Travel \& Tourism Competitiveness Report 2011. Beyond the Downturn. Geneva, Switzerland. Available from: http://es.scribd.com/doc /49473673/Travel-Tourism-Competitiveness-Report-2011

- World Tourism Organization -UNWTO-. (2011). UNWTO Tourism Highlights 2011 Edition. Available from:

http://mkt.unwto.org/sites/all/files/docpdf/unwtohighlights11enlr.pdf

- Yaniv, P., Arie, R. and Yael, B. (2011). “Dimensions of hotel experience of people with disabilities: An exploratory study”. International Journal of Contemporary Hospitality Management, 23(5): 571-591.

- Yau, M., McKercher, B. and Packer, T. (2004). “Traveling with a disability: More than an Access Issue”. Annals of Tourism Research, Vol. 31 (4): 946-960.

- Yoon, Y. and Uysal, M. (2005). “An examination of the effects of motivation and satisfaction on destination loyalty: a structural model”. Tourism Management, Vol. 26 (2): 45-56. 


\section{Table 1:Dimensions of disability}

\begin{tabular}{|c|c|c|}
\hline $\begin{array}{l}\text { Type of } \\
\text { impairment }\end{array}$ & Description & Difficulties in one of more of the following areas \\
\hline Physical/mobility & $\begin{array}{l}\text { Varying levels of physical } \\
\text { mobility restrictions, affecting } \\
\text { legs, feet, back, neck, arms or } \\
\text { hands }\end{array}$ & $\begin{array}{ll} & \text { physical and motor tasks } \\
\text { - } & \text { independent movements } \\
\text { - } & \text { performing basic life functions }\end{array}$ \\
\hline Sensory & $\begin{array}{l}\text { Capacity to see is limited or } \\
\text { absent } \\
\text { Completely deaf or are hard of } \\
\text { hearing } \\
\text { Limited, impaired or delayed } \\
\text { capacities to use expressive } \\
\text { and/or receptive language }\end{array}$ & $\begin{array}{ll}\text { - } & \text { reduced performance in tasks requiring } \\
\text { clear vision } \\
\text { - } & \begin{array}{l}\text { difficulties with written communication } \\
\text { difficulties with understanding information } \\
\text { presented visually }\end{array} \\
\text { - } & \text { reduced performance in tasks requiring } \\
\text { sharp hearing } \\
\text { - difficulties with oral communication } \\
\text { - difficulties in understanding auditorally- } \\
\text { presented information }\end{array}$ \\
\hline $\begin{array}{l}\text { Cognitive } \\
\text { (Intellectual/mental } \\
\text { health) }\end{array}$ & $\begin{array}{l}\text { Lifelong illnesses with multiple } \\
\text { aetiologies that result in a } \\
\text { behavioural disorder }\end{array}$ & $\begin{array}{ll}\text { - } & \text { slower rate of learning } \\
\text { - } & \text { disorganised patterns of learning } \\
\text { - } & \text { difficulties with adaptive behaviour } \\
\text { - } & \text { difficulties understanding abstract concepts } \\
\text { - } & \text { limited control of cognitive functioning } \\
\text { - } & \text { problems with sensory, motor and speech } \\
& \text { skills } \\
\text { - } & \text { restricted basic life functions }\end{array}$ \\
\hline
\end{tabular}


Source: adapted from Buhalis \& Darcy (2011) and Domínguez, Alén \& Fraiz (2012). 


\section{Table 2: Main competitiveness factors and attributes: Crouch's model and its application to Australian and Spanish accessible destinations}

\begin{tabular}{|c|c|c|}
\hline Crouch's model & Proposal model for Australia and Spain & \\
\hline Core resource and attractors & Core resource and attractors & \\
\hline - $\quad$ Physiography and climate (P\&C) & - $\quad$ Physiography and climate (P\&C) & \\
\hline - $\quad$ Mix of activities (ACT) & - $\quad$ Mix of activities (ACT) & Accessibility level \\
\hline - $\quad$ Culture and history (C\&H) & - $\quad$ Culture and history (C\&H) & Accessibility number \\
\hline - $\quad$ Tourism superstructure (TSUPER) & - $\quad$ Tourism superstructure (TSUPER) & \\
\hline - $\quad$ Special events (EVENT) & - Market ties (MARKT) & \\
\hline - $\quad$ Market ties (MARKT) & - $\quad$ Entertainment (ENTRE) & \\
\hline - $\quad$ Entertainment (ENTRE) & & \\
\hline Supporting factors and resources & Supporting factors and resources & \\
\hline - Accessibility (ACCESS) & - Accessibility (ACCESS) & Accessibility level \\
\hline - $\quad$ Infrastructure (INFRAST) & - $\quad$ Infrastructure (INFRAST) & Accessibility number \\
\hline - $\quad$ Hospitality (HOSP) & - $\quad$ Hospitality (HOSP) & \\
\hline $\begin{array}{l}-\quad \text { Political will (POLITW) } \\
\text { Qualifying and amplifying determinants }\end{array}$ & $\begin{array}{l}\text { - Political will (POLITW) } \\
\text { (POale }\end{array}$ & \\
\hline & & \\
\hline - Cost/Value (C\&V) & - Cost/Value (C\&V) & Accessibility level \\
\hline - $\quad$ Location (LOCAT) & - $\quad$ Location (LOCAT) & \\
\hline - $\quad$ Safety/Security (S\&S) & - Safety/Security (S\&S) & Accessibility number \\
\hline $\begin{array}{l}\text { - Awareness/Image (A\&I) } \\
\text { Destination management }\end{array}$ & $\begin{array}{l}-\quad \text { Awareness/Image (A\&I) } \\
\text { Destination planning and management }\end{array}$ & \\
\hline - $\quad$ Quality of services/experience (QSER) & - Quality of services/experience (QSER) & Accessibility level \\
\hline Destination policy, planning and development & - $\quad$ Positioning and branding $(\mathrm{P} \& \mathrm{~B})$ & $\overline{\text { Accessibility number }}$ \\
\hline - $\quad$ Positioning and branding (P\&B) & & \\
\hline
\end{tabular}




\section{Table 3: Factorialanalysis of competitiveness factors and attributes}

\section{FACTOR}

Core resource and attractors
AUSTRALIA

Cronbach Alpha

0.911

\section{SPAIN}

Cronbach Alpha

0.915

ATTRIBUTES Component Matrix \% Variance Explained Component Matrix \% Variance Explained

Physiography and climate .906

Mix of activities

Culture and history

Tourism superstructure

Special events

Market ties

Entertainment
.878

.891

.877

.811

.755

.806
.887

.846

.832

.860

.711

.764

.836

FACTOR

Cronbach Alpha

0.914

Supporting factors and

resources

ATTRIBUTES Component Matrix \% Variance Explained Component Matrix \% Variance Explained

Accessibility

Infrastructure

Hospitality

Political will

$$
.910
$$

.922

.840

.893
.841

.791

.815

.797

FACTOR

Cronbach Alpha

0.808

67.466

Cronbach Alpha

0.818

Qualifying and amplifying

determinants

ATTRIBUTES Component Matrix \% Variance Explained Component Matrix \% Variance Explained

Cost/Value

Location

Safety/Security

Awareness/Image

FACTOR
$-.807$

.827

.582

.895
$-.732$

.888

.542

.884

Cronbach Alpha

0.923

Destination planning and

management

0.913

65.818

Cronbach Alpha

0.459 
Table 4: Competitiveness attributes determinance measures

AUSTRALIA

\begin{tabular}{|c|c|c|c|c|c|c|c|c|c|c|}
\hline & $\begin{array}{c}\text { Std. } \\
\text { Deviation }\end{array}$ & $\begin{array}{l}\text { Std. } \\
\text { Error } \\
\text { Mean }\end{array}$ & $\begin{array}{c}\text { Mean } \\
\text { Difference }\end{array}$ & $\begin{array}{c}t \\
\text { Statistic }\end{array}$ & $\begin{array}{c}\text { Significance } \\
\text { level (2- } \\
\text { tailed) }\end{array}$ & $\begin{array}{c}\text { Std. } \\
\text { Deviation }\end{array}$ & $\begin{array}{l}\text { Std. } \\
\text { Error } \\
\text { Mean }\end{array}$ & $\begin{array}{c}\text { Mean } \\
\text { Difference }\end{array}$ & $\begin{array}{c}t \\
\text { Statistic }\end{array}$ & $\begin{array}{c}\text { Significance } \\
\text { level (2- } \\
\text { tailed) }\end{array}$ \\
\hline $\mathrm{P} \& \mathrm{C}$ & 1.00881 & .12916 & 1.74590 & 13,517 & ,000 & .84107 & 11663 & 1.69231 & 14,509 & ,000 \\
\hline ACT & 1.08784 & .13928 & 1.59016 & 11,417 & ,000 & 1.00493 & .13936 & 1.90865 & 13,696 & ,000 \\
\hline $\mathrm{C} \& \mathrm{H}$ & .81606 & .10449 & 1.31148 & 12,552 & ,000 & .81476 & .11299 & 1.48077 & 13,106 & ,000 \\
\hline TSUPER & .92963 & .11903 & 1.79918 & 15,116 & ,000 & 1.15498 & .16017 & 2.14904 & 13,418 & ,000 \\
\hline S\&S & .49764 & .06372 & 1.73361 & 27,208 & ,000 & .50551 & .07010 & 2.10096 & 29,970 & ,000 \\
\hline $\mathrm{C} \& \mathrm{~V}$ & .56979 & .07295 & 2.03689 & 27,920 & ,000 & .55758 & .07732 & 1.76923 & 22,881 & ,000 \\
\hline ACCESS & .92779 & .11879 & 1.54098 & 12,972 & ,000 & 1.13356 & .15720 & 1.89904 & 12,081 & ,000 \\
\hline EVENT & .70430 & .09018 & .72131 & 7,999 & 000 & .82914 & .11498 & .74519 & 6,481 & ,000 \\
\hline A\&I & .85778 & .10983 & 1.29098 & 11,755 & 000 & 1.06026 & .14703 & 1.47115 & 10,006 & ,000 \\
\hline LOCAT & .80170 & .10265 & 1.20492 & 11,738 & 000 & 1.00642 & .13957 & 1.72596 & 12,367 & ,000 \\
\hline INFRAST & .82850 & .10608 & 1.53279 & 14,450 & 000 & .90863 & .12600 & 2.26923 & 18,009 & ,000 \\
\hline HOSP & .81457 & .10430 & 1.50410 & 14,422 & 000 & .75563 & .10479 & 1.74038 & 16,609 & ,000 \\
\hline MARKT & .60677 & .07769 & .66803 & 8,599 & ,000 & .75124 & .10418 & 1.35096 & 12,968 & ,000 \\
\hline ENTRE & .79245 & .10146 & 1.23770 & 12,199 & 000 & .94014 & .13037 & 1.69231 & 12,980 & ,000 \\
\hline QSER & .65971 & .08447 & 1.06557 & 12,615 & ,000 & .89509 & .12413 & 1.33654 & 10,768 & ,000 \\
\hline POLITW & 89483 & .11457 & 1.17623 & 10,266 & ,000 & 1.00060 & 13876 & 1.49519 & 10,776 & 000 \\
\hline $\mathrm{P} \& \mathrm{~W}$ & 1.03043 & 13193 & 1.31148 & 9,940 & ,000 & .97811 & .13564 & 1.32212 & 9,747 & ,000 \\
\hline
\end{tabular}


Table 5: Estimated importance weight

\section{AUSTRALIA}

$\begin{array}{ccc}\text { Extraction } & \text { Extraction } & \\ \text { Component } & \text { Component } & \text { TOTAL } \\ \text { Matrix } & \text { Matrix } & \\ & & \end{array}$

\section{SPAIN}

Extraction

Component

Matrix

FACTORS

\section{Extraction}

Component TOTAL

Matrix

CORE RESOURCES AND ATTRACTORS

$\begin{array}{ccccccc}\text { P\&C } & .973 & .906 & 0.88112894 & .967 & .887 & 0.857491423 \\ \text { ACT } & .973 & .878 & 0.85438007 & .967 & .846 & 0.817612114 \\ \text { C\&H } & .973 & .891 & 0.86711076 & .967 & .832 & 0.804616237 \\ \text { TSUPER } & .973 & .877 & 0.85338926 & .967 & .860 & 0.831996056 \\ \text { EVENT } & .973 & .811 & 0.7888635 & .967 & .711 & 0.687688868 \\ \text { MARKT } & .973 & .755 & 0.73463234 & .967 & .764 & 0.739258084 \\ \text { ENTRE } & .973 & .806 & 0.78438926 & .967 & .836 & 0.808242523 \\ & & \text { SUPPORTING FACTORS AND RESOURCES } & & \\ \text { ACCESS } & .956 & .910 & 0.86966598 & .965 & .841 & 0.811565 \\ \text { INFRAST } & .956 & .922 & 0.88127671 & .965 & .791 & 0.763315 \\ \text { HOSP } & .956 & .840 & 0.80334557 & .965 & .815 & 0.786475 \\ \text { POLITW } & .956 & .893 & 0.85392212 & .965 & .797 & 0.769105\end{array}$

QUALIFYING AND AMPLIFYING DETERMINANTS

\begin{tabular}{ccccccc} 
C\&V & .948 & -.807 & -0.7651633 & .936 & -.732 & -0.684730217 \\
LOCAT & .948 & .827 & 0.78438367 & .936 & .888 & 0.831427474 \\
S\&S & .948 & .582 & 0.55206921 & .936 & .542 & 0.507485356 \\
A\&I & .948 & .895 & 0.84802264 & .936 & .884 & 0.827386236 \\
\multicolumn{7}{c}{ DESTINATION PLANNING AND MANAGEMENT } \\
QSER & .963 & .962 & 0.92609883 & .931 & .881 & 0.820211 \\
P\&W & .963 & .961 & 0.925443 & .931 & .882 & 0.821538226
\end{tabular}


Table 6: Australian and Spanish Accessible Destination Competitiveness Ranking AUSTRALIA SPAIN

$\begin{array}{cccc}\text { Importance } & \text { Determinance } & \text { Importance } & \text { Determinance } \\ \text { Ranking } & \text { Ranking } & \text { Ranking } & \text { Ranking }\end{array}$

Core resource and attractors

1

Destination planning and management

2

Supporting factors and resources 3

Qualifying and amplifying determinants

Quality of services/experience (QSER)

Positioning and branding (P\&B)

Infrastructure (INFRAST)

Physiography and climate (P\&C)

Accessibility (ACCESS)

Culture and history $(\mathrm{C} \& \mathrm{H})$

Mix of activities (ACT)

Political will (POLITW)

Tourism superstructure (TSUPER)

Awareness/Image (A\&I)

Hospitality (HOSP)

Special events (EVENT)

Entertainment (ENTRE)

Location (LOCAT)

Cost/Value (C\&V)

Market ties (MARKT)

Safety/Security (S\&S)

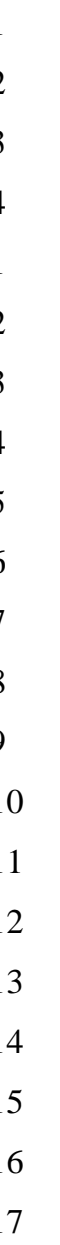

$\begin{array}{lll}3 & 1 & 3 \\ 4 & 4 & 4 \\ 2 & 2 & 1 \\ 1 & 3 & 2 \\ 15 & 6 & 15 \\ 10 & 5 & 16 \\ 7 & 13 & 1 \\ 3 & 1 & 9 \\ 6 & 8 & 5 \\ 9 & 10 & 12 \\ 5 & 7 & 4 \\ 14 & 12 & 11 \\ 2 & 2 & 2 \\ 11 & 4 & 13 \\ 8 & 11 & 7 \\ 16 & 15 & 17 \\ 12 & 9 & 10 \\ 13 & 3 & 8 \\ 1 & 16 & 6 \\ 17 & 14 & 14 \\ 4 & 17 & 3\end{array}$


Table 7: Australian and Spanish k-means clustering analysis

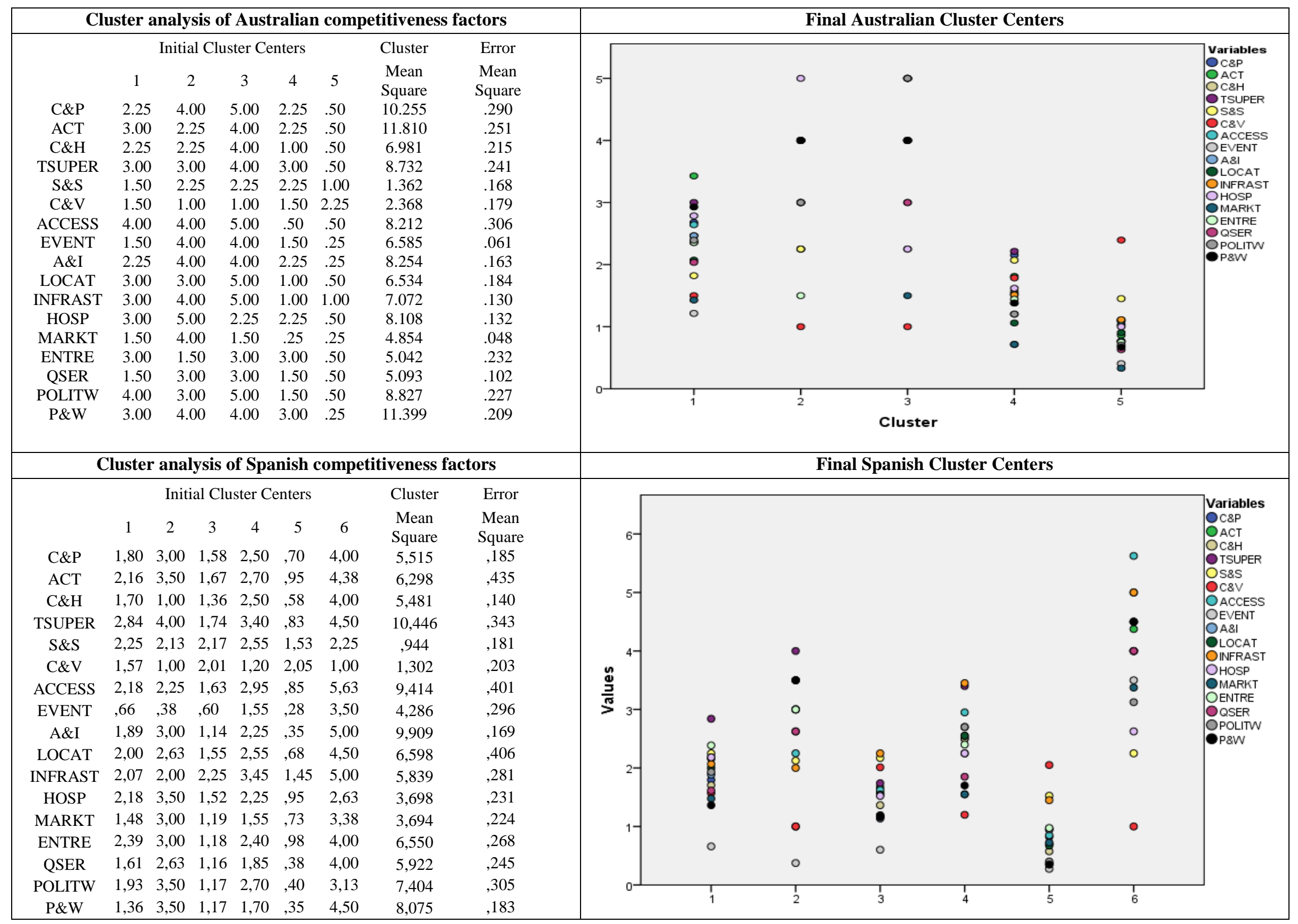


Table 8: Tourism destinations clusters

\begin{tabular}{|c|c|c|}
\hline \multicolumn{3}{|r|}{ Australian Cases in each Cluster } \\
\hline Cluster & Cases & Destinations \\
\hline 1 & 7 & $\begin{array}{l}\text { Brisbane, Tropical North Queensland, Adelaide City, Kangaroo Island, Hobart , North West } \\
\text { Coast , Western Wilderness }\end{array}$ \\
\hline 2 & 1 & (2: \\
\hline 3 & 1 & Melbourne \\
\hline 4 & 21 & $\begin{array}{l}\text { Australia capital territory, North Coast, Darwin, Kakadu and Arnhem Land , Alice Springs, Uluru, } \\
\text { Capricornia, Fraser Coast, Gold Coast, Sunshine Coast, Townsville, Limestone Coast, East } \\
\text { Coast, Lacenston Tamar and North, Philip Island, Great Ocean Road, Gippsland, Expierence } \\
\text { Perth, Australia's north West, Australia's South West }\end{array}$ \\
\hline 5 & 31 & $\begin{array}{l}\text { Bleu Montains, Country NSW, Hunter, Lord Howe Island, Outback NSW, Snowy Mountains, } \\
\text { South Coastal, Katherine, Tennant Creek and Barkly Region, Bundaberg, Gladstone, Mackay, } \\
\text { Outback Queensland, Southern Queensland Country, The Whitsundays, Adelaide Hills, Barossa, } \\
\text { Clare Valley, Eyre Peninsula,Fleurie Peninsula,Flinders Ranges and Outback, Murray River,Yorke } \\
\text { Peninsula,Yarra Valley and Dandenong Ranges, Goldfields, Grampians, High Country, The } \\
\text { Murray, Australia's Coral Coast, Australia's Golden Outback }\end{array}$ \\
\hline \multicolumn{3}{|r|}{ Spanish Cases in each Cluster } \\
\hline Cluster & Cases & Destinations \\
\hline 1 & 7 & Baleares, Toledo, Tarragona, Murcia, Vitoria, Bilbao, San Sebastián \\
\hline 2 & 2 & Santa Cruz de Tenerife, Alicante \\
\hline 3 & 22 & $\begin{array}{l}\text { Almería, Córdoba, Granada, Málaga, Asturias, Las Palmas, Cantabria, Ávila, Burgos, Palencia, } \\
\text { Salamanca, Segovia, Valladolid, Ciudad Real, Guadalajara, Girona, Castellón, Badajoz, A Coruña, } \\
\text { Lugo, Pontevedra, La Rioja }\end{array}$ \\
\hline 4 & 4 & Sevilla, Zaragoza, Lleida, Valencia \\
\hline 5 & 15 & $\begin{array}{l}\text { Cádiz, Huelva, Jaén, Huesca, Teruel, León, Soria, Zamora, Albacete, Cuenca, Cáceres, Ourense, } \\
\text { Navarra, Ceuta, Melilla }\end{array}$ \\
\hline 6 & 2 & Barcelona, Madrid \\
\hline
\end{tabular}

